\title{
Kajian Sistem Budidaya Tanaman Sawi (Brassica juncea L) Di Petani Kelurahan Malawele Distrik Aimas Kabupaten Sorong
}

\author{
Zulkarnain Sangaji \\ Dosen Fakultas Pertanian Universitas Muhammadiyah Sorong
}

\begin{abstract}
Abstraks
Penelitian bertujuan untuk mengetahui teknik-teknik budidaya tanaman sawi (Brassica juncea L) yang dilakukan petani di di Kelurahan Malawele Distrik Aimas Kabupaten Sorong. P Petani budidaya tanaman sawi di Distrik Aimas masih melakukan kegiatan budidaya tanaman sawi yang belum sesuai standar yang ada seperti pada kegiatan pemupukan yang dilakukan dengan sistem tabur, tidak digunakan jarak tenam tertentu karena benih menggunakan sistem sebar pada areal lahan sehingga kepadatan tanaman tinggi dan ketergantungan pada pemberian pupuk anorganik. Metode penelitian yang digunakan yaitu metode kuantitatif maupun kualitatif.
\end{abstract}

Kata Kunci: system, budidaya, tanaman sawi, petani.

\section{PENDAHULUAN}

Pada umumnya tanaman hortikultura merupakan komoditas yang memiliki prospektif yang sangat baik untuk dikembangkan, karena memiliki nilai ekonomis yang sangat tinggi khususnya bagi para petani. Tanaman Hortikultura diantaranya yaitu buahbuahan, obat-obatan, tanaman hias serta sayur-sayuran. Di Indonesia ini memungkinkan dikembangkan tanaman sayur-sayuran yang banyak bermanfaat bagi pertumbuhan dan perkembangan bagi manusia.Sehingga ditinjau dari aspek klimatologis Indonesia sangat tepat untuk dikembangkan untuk bisnis sayuran.Di antara tanaman sayursayuran yang mudah dibudidayakan adalah sawi.Karena sawi ini sangat mudah dikembangkan dan banyak kalangan yang menyukai dan memanfaatkannya.Selain itu juga sangat potensial untuk komersial dan prospek sangat baik (Anonim, 2010).

Sawi adalah sekelompok tumbuhan dari marga Brassica yang dimanfaatkan daun atau bunganya sebagai bahan pangan (sayuran), baik segar maupun diolah. Sawi mencakup beberapa spesies Brassicayang kadangkadang mirip satu sama lain. Di Indonesia penyebutan

sawibiasanya mengacu pada sawi hijau (Brassica

rapa kelompok parachinensis, yang disebut juga sawi bakso, caisim, atau caisin). Selain itu, terdapat pula sawi putih (Brassica

rapa) kelompok pekinensis, disebut juga petsai yang biasa dibuat sup atau diolah menjadi asinan.Jenis lain yang kadang-kadang disebut sebagai sawi hijau adalahsawi sayur (untuk membedakannya dengan caisim).

Kailan (Brassicaoleracea) kelo mpok alboglabraadalah sejenis sayuran daun lain yang agak berbeda, karena daunnya lebih tebal dan lebih cocok menjadi bahan campuran mi goreng. Sawi sendok (pakcoy atau bok choy) merupakan jenis sayuran daun kerabat sawi yang mulai dikenal pula 
dalam dunia boga Indonesia (Yudharta, 2009). Selain memiliki keragaman jenis, sawi juga memiliki kandungan gizi yang cukup tinggi. Menurut Direktorat Gizi Departemen Kesehatan Republik Indonesia, kandungan gizi tanaman sawi dalam $100 \mathrm{~g}$ bahan yang dapat dimakan mengandung energi 22,00 kalori, protein 2,30 g, lemak 0,30 $\mathrm{g}$, karbohidrat $4,00 \mathrm{~g}$, serat $1,20 \mathrm{~g}$, kalsium $220,50 \mathrm{mg}$, fosfor $38,40 \mathrm{mg}$, zat besi 2,90 mg, vitamin A 969,00 SI, thiamine $0,09 \mathrm{mg}$, riboflavin 0,10 $\mathrm{mg}$, niacin $0,70 \mathrm{mg}$, vitamin C 102,00 mg (Cahyono, 2003). Besarnya nilai manfaat tanaman sawi sehingga permintaan akan kebutuhan tanaman sawi terus meningkat setiap tahun.

Jumlah penduduk Indonesia yang semakin bertambah serta meningkatkannya kesadaran akan kebutuhan gizi yang menyebabkan bertambahnya permintaan yang tinggi pada tanaman sawi tersebut, ditambah peluang pasar internasional yang cukup besar bagi sawi layak diusahakan di tinjau dari aspek ekonomi atau bisnis (Haryanto dkk,2002). Permintaan pasar untuk ekspor sawi cukup besar yakni 72 ton pertahun sementara setiap tahunnya hanya mampu menyediakan 25 ton pertahun . Rendahnya produk sawi disebabkan olek karena beberapa hambatan antara lain kurangnya panca usaha tani yakni penggunaan variabel unggul, pemupukan, pengairan, pengendalian hama dan penyakit, serta lahan yang tersedia. Sehingga yang sangat perlu diperhatikan dalam meningkatkan produtivitas tanman sawi adalah pada teknik budidaya tanamannya.

Distrik Aimas sebagai bagian dari wilayah Provinsi Papua Barat yang merupakan salah satu bagian Distrik di Kabupaten Sorong yang menjadi sentra pengembangan tanaman pertanian terutama sayur-sayuran. Sejauh ini petani banyak menanam tanaman sawi sebagai komoditas potensial yang bersifat komersial dalam meningkatkan ekonomi keluarga. Berbagai teknik kegiatan budidaya telah dilakukan petani guna meningkatkan hasil dari tanaman sawi, namun terkadang sistem budidaya yang diterapkan masih jauh dari standar yang ditetapkan. Bukan hanya produksi yang harus diperhatikan dalam keberhasilan budidaya tanaman sawi tetapi juga yang harus diperhatikan adalah bagaimana petani menerapkan teknik budidaya yang tetap pada keberlanjutkan lahannya.

\section{METODE PENELITIAN}

\section{Tempat Dan Waktu}

Penelitian akan dilaksanakan di kebun petani di Aimas Kelurahan Malawele Kabupaten Sorong. Penelitian berlangsung pada bulan September sampai bulan Nopember 2016.

\section{Bahan Dan Alat}

Bahan dan alat yang digunakan dalam penelitian ini adalah kuisioner, kamera, alat tulis menulis dan petani tanaman sawi yang digunakan sebagai objek penelitian.

\section{Metode Pengumpulan Data}

Tujuan yang ingin dicapai pada metode pengumpulan data adalah memperoleh data dan informasi, baik yang bersifat kuantitatif maupun kualitatif. Untuk mencapai tujuan tersebut maka dilakukan hal-hal sebagai berikut :

\section{Responden}

Responden dalam penelitian ini adalah petani yang mengusahakan 
sistem Budidaya Tanaman sawi di Kelurahan Malawele Distrik Aimas Kabupaten Sorong. Pemilihan responden dilakukan secara porposive sampling pada petani yang menanam tanaman sawi. .

\section{Jenis Data}

Berdasarkan jenis data yang dibutuhkan, pengumpulan data dan informasi lainnya dilakukan dengan menggunakan dua teknik pengambilan data yaitu data primer dan data sekunder. Data primer dilakukan melalui wawancara langsung dengan responden yang terpilih. Data tersebut di antaranya adalah karak teristik responden (umur/usia, jenis kelamin, pendidikan, kepemilihan lahan, luas lahan, jenis tanaman yang diusahakan, pengolahan tanah, pembibitan, tindakan pemeliharaan, pemanenan, pemasaran. Sedangkan data sekunder di kumpulkan melalui instansi-instansi terkait yaitu kantor Dinas Pertanian untuk memperoleh data yang berkaitan dengan tujuan penelitianini.

\section{Teknik Pengumpulan Data}

Teknik pengambilan data yang digunakan dalam penelitian ini adalah wawancara langsung dengan responden. Bahan pengumpulan data yang dibutuhkan adalah kuisioner dan disertai dengan pengambilan gambar kondisi lahan yang dimiliki dimiliki responden.

\section{Analisis Data}

Data yang diperoleh di analisis secara deskriptif kualitaf untuk meneggambarkan teknik-teknik budidaya tanaman sawi yang dilakukan oleh petani di Kelurahan Malawele Distrik aimas Kabupaten Sorong.

\section{HASIL DAN PEMBAHASAN}

\section{Karakteristik Responden}

Karakteristik responden yang diteliti dalam penelitian ini meliputi usia, jenis kelamin, tingkat pendidikan formal, luas kepemilikan lahan, serta pekerjaan pokok. Adapun karakteristik petani responden yaitu sebagai berikut:

\section{Usia}

Usia petani responden sangat beragam, mulai dari 42 tahun hingga usia 62 tahun. Usia petani responden dapat dikelompokkan dalam usia produktif (15-64 tahun) serta usia non Produktif ( $\geq 65$ tahun). Karakteristik usia petani responden dapat dilihat pada tabel 1 .

Tabel 1. Karakteristik Usia Petani Responden

\begin{tabular}{ccc}
\hline Usia (tahun) & Jumlah (orang) & Persentase (\%) \\
\hline a. Produktif $(15-64$ th) & 10 & 100 \\
b. Non produktif $(\geq 65$ th) & - & - \\
\hline
\end{tabular}

Sumber : analisis data primer

Berdasarkan tabel 1 diketahui bahwa mayoritas usia petani responden yang membudidayakan sawi tergolong usia produktif (15-64 tahun) yaitu sebanyak $100 \%$ petani berada dibawah umur 64 tahun sehingga umur ini bisa dikatakan petani lebih mempunyai sifat terbuka dalam menerima inovasi teknologi budidaya tanaman sawi. Usia dapat mempengaruhi responden dalam merespon sesuatu yang diterimanya, selain itu juga terkait dengan kondisi 
fisik atau aktifitas dalam berusahatani. Petani yang tergolong usia non produktif cenderung sulit menerima inovasi, karena keterbatasan fisik dan cenderung tertutup atau kolot.

\section{Jenis kelamin}

Jenis kelamin petani responden dapat dibedakan menjadi laki-laki dan perempuan. Dalam budidaya tanaman sawi, jenis kelamin sangat menentukan aktifitas budidaya tanaman. Karakteristik jenis kelamin petani responden dapat dilihat pada tabel 2 .

Tabel 2. Karakeristik Jenis Kelamin Petani Responden

\begin{tabular}{ccc}
\hline Jenis Kelamin & Jumlah (orang) & Persentase (\%) \\
\hline a. Laki-laki & 10 & 100 \\
b. Perempuan & - & - \\
\hline
\end{tabular}

Sumber : analisis data primer

Tabel 2 menunjukkan bahwa petani yang menanam tanaman sawi rata-rata adalah laki-laki yaitu sebanyak 10 orang responden (100 \%) yang semuanya adalah laki-laki. Hal ini karena kaum perempuan hanya berperan sebagai tenaga bantuan dalam budidaya tanaman sawi dan dalam pengambilan keputusan juga kaum laki-laki yang memegang peranan penting.

\section{Luas Kepemilikan Lahan}

Luas kepemilikan lahan yang dimiliki petani tanaman sawi tidak semuanya mempunyai hak miliki pribadi tetapi sebagian merupakan lahan sewa dari petani lainnya. pengusaan lahan dapat mempengaruhi tingkat produksi tanaman sawi yang dihasilkan. Karakteristik luas kepemilikan lahan petani responden dapat dilihat pada tabel 3 .

Tabel 3. Karakteristik luas kepemilikan lahan budidaya tanaman sawi petani responden

\begin{tabular}{ccc}
\hline Luas kepemilikan Lahan & Jumlah (orang) & Persentase (\%) \\
\hline a. $<0,5 \mathrm{Ha}$ & 1 & 10 \\
b. $0,6-0,8 \mathrm{Ha}$ & 3 & 30 \\
c. $>0,9 \mathrm{Ha}$ & 6 & 60 \\
\hline
\end{tabular}

Sumber : analisis data primer

Berdasarkan tabel 3 rata-rata [etani responden memiliki lahan dengan luas antara 0,5-3 Ha. Lahan tersebut sebagian adalah milik sendiri sedangkan sebagian adalah lahan sewaan. Dan lahan yang digunakan yaitu lahan kering, sehingga untuk memenuhi kebutuhan air untuk pertanaman biasanya diperoleh dari air sumur, sumur bor, kolam dan air hujan/

\section{Pendidikan Formal}

Pendidikan formal petani di Distrik Aimas terdiri dari yang tidak sekolah sampai dengan tamat jenjang pendidikan sekolah dasar (SD) sampai Sekolah Menengah Pertama (SLTP). Tingkat pendidikan dianggap mempengaruhi cara berpikir petani dalam mengambil suatu keputusan dan dalam pengembangan budidaya sistem pertaniannya. Karakteristik pendidikan formal petani responden dapat dilihat pada tabel 4 
Tabel 4. Karakteristik Pendidikan Formal Petani Responden

\begin{tabular}{ccc}
\hline Pendidikan Formal & Jumlah (orang) & Persentase (\%) \\
\hline a. Tidak Sekolah & 1 & 10 \\
b. Tamat SD & 8 & 80 \\
c. Tamat SLTP & 1 & 10 \\
d. Tamat SLTA & - & - \\
\hline
\end{tabular}

Sumber : analisis data primer

Tabel 4 menunjukkan bahwa tingkat pedidikan formal petani yang membudidayakan sawi rata-rata yaitu tamat SD sebanyak 8 orang responden $(80 \%), 1$ orang tamatan SD $(10 \%)$ dan 1 orang tidak tamat sekolah (10\%). Tingkat pendidikan responden sangat mempengaruhi kemampuan dalam penerimaan inovasi yang diberikan.

\section{Sistem Budidaya Tanaman Sawi di Distrik Aimas Kabupaten Sorong}

Keberhasilan budidaya tanaman sawi tidak terlepas dari berbagai macam faktor atau aspek yang meliputi Persiapan lahan dan pengolahan tanah, penerapan pola tanam, jenis varietas yang ditanam, pemupukan, penerapan cara tanam, pemeliharaan tanaman, serta pemanenan. Budidaya tanaman sawi dilakukan melalui tahapan sebagai berikut :

\section{Pengolahan tanah dan persiapan lahan}

Dalam budidaya tanaman sawi, rata-rata petani di Distrik Aimas melakukan tahapan pada pengolahan tanah yang meliputi pembuatan bedengan dan penggemburan yaitu dengan melakukan pencangkulan untuk memperbaiki struktur tanah dan pemberian pupuk dasar (pupuk kandang). Hal ini bertujuan untuk memperbaiki struktur tanah dan sirkulasi udara dan memberian pupuk dasar agar untuk memperbaiki fisik dan kimia tanah dan menambah kesuburan lahan yang akan ditanami.

\section{Pola Tanam}

Pola tanam yang dilakukan oleh petani yaitu dengan melakukan penanaman dengan periode tanam per bulan sehingga dalam setahun terdapat 11-12 kali penanaman sawi pada luasan lahan yang disediakan. Sistem penanaman yang dilakukan yaitu bersifat monokultur. Sistem monokultur adalah pola tanam yang dilakukan secara tunggal, dimana pada sebidang tanaha hanya ditanami satu jenis tanaman budidaya. Meskipun dalam luasan 1 heektar terdapat beberapa jenis tanaman namun untuk penanaman sawi dilakukan pada luasan lahan dalam setiap bedengan yanng memang disediakan untuk tanaman sawi tanpa ada kombinasi tanaman lain.

\section{Varietas}

Penggunaan benih sawi oleh petani di Distrik Aimas diperoleh atau didapatkan dengan cara dibeli pada 
toko-toko usaha tani. Perbanyakan benih melalui pertanaman jarang dilakukan petani dan perolehan benih langsung dilakukan dengan pembelian benih yang dijual di toko usaha tani karena dianggap lebih praktis. Benih yang diperoleh dari toko dengan merek dagang tosakan mmpunyai karakteristik jenis sawi yang dapat di tanam pada daerah dataran rendah, menghasilkan tanaman yang berunga lambat, berbatang tegak dengan daun yang tebal dan renyah, sedikit berserat dan tahan terhadap hama dan penyakit serta dapat dipanen ketika berumur sekitar 25-30 har

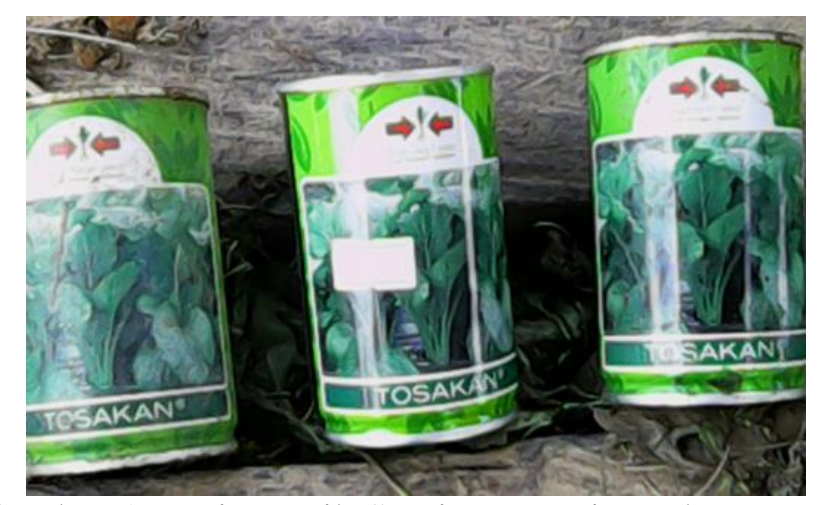

Gambar 1. Jenis Benih Sawi Yang Digunakan Petani

\section{Penyiapan benih}

Untuk mendapatkan benih yang berkualitas, petani cendengan menggunakan benih yang dijual di toko daripada yang diperoleh melalui perbanyakan tanaman. penggunaan benih dalam penanaman yaitu sebanyak 100 gram per lahan yang dimiliki.

\section{Masa Tanam}

Masa tanam atau periode tanam pada tanaman sawi dilakukan hampir setiap bulan dengan umur panen berkisar antara 25-30 hari. Hal ini juga sesuai dengan penggunaan benih yang mempunyai umur panen 25-30 hari, sehingga penanaman sawi dilakukan petani dalam periode perbulan sehingga dalam setahun bisa menaman sebanyak 12 kali.

\section{Cara penanaman}

Rata-rata cara penanaman yang dilakukan petani di Distrik Aimas menggunakan sistem tebar benih pada lahan yang sudah dipersiapkan. Setelah lahan diolah dan diberikan pupuk kandang maka benih akan ditabr dibedengyang telah disiapkan untuk pertanaman 


\section{Median Volume IX Nomor 1 Bulan Februari}

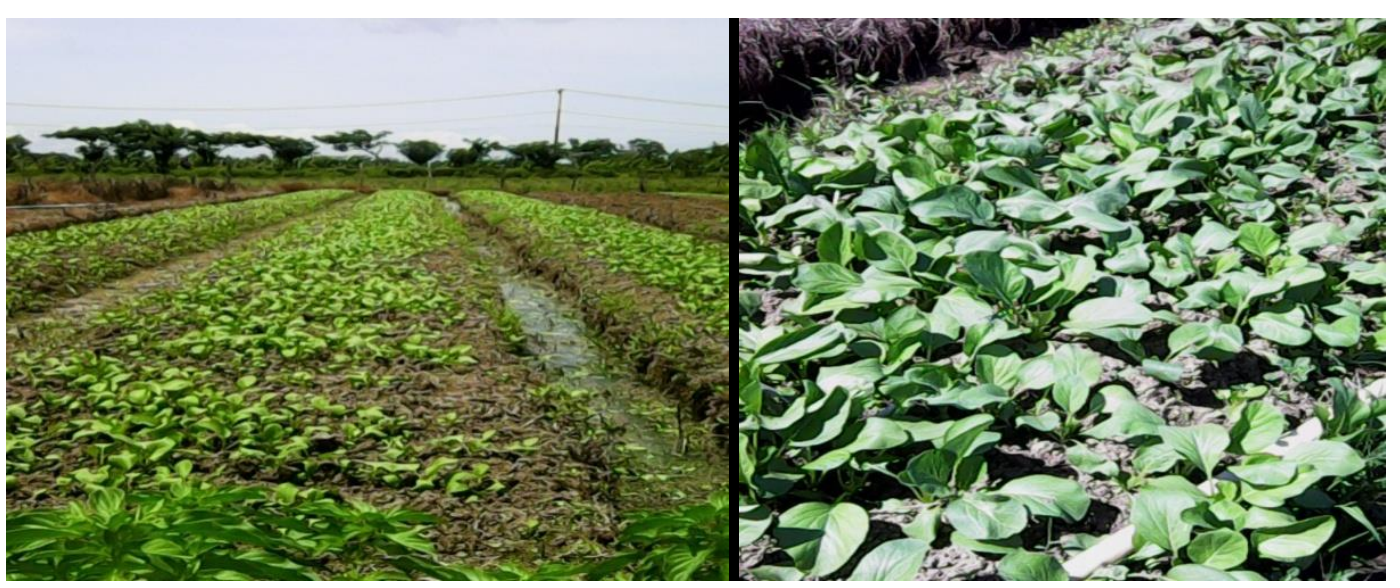

Gambar 2. Kondisi Pertanaman sawi dengan sistem Tebar

\section{Pemeliharaan Tanaman}

Pemeliharaan tanaman sawi dilakukan melalui berbagai macam kegiatan yang meliputi penyiraman, penyulaman, penyiangan, pemupukan, pembumbunan dan pemberantasan hama dan penyakit.

\section{a. Penyiraman}

Penyiraman pada tanaman sawi biasanya dilakukan tergantung pada musim hujan. Apabila musim hujan berlebihan maka tidak dilakukan penyiraman. Tetapi apabila memasuki musim kemarau maka petani akan melakukan penyiraman minimal sekali dalam sehari. Penyiraman ini dilakukan pada saat pagi atau sore hari. Tetapi biasanya petani di distrik aimas lebih cenderung melakukan penyiraman di waktu sore hari. Sumber air yang digunakan diperoleh dari sumur ataupun kolam-kolam yang ada disekitar lahan.

\section{b. Penyulaman}

Petani di Distrik Aimas melakukan penyulaman apabila terdapat tanaman yang mati atau terserang hama dan penyakit. Apabila ditemui tanaman yang mati ataupun terserang hama dan penyakit pada beberapa tanaman maka biasanya petani langsung melakukan penyulaman untuk menggantikan tanaman yang mati tersebut.

\section{c. Penyiangan}

Kegiatan penyiangan dilakukan oleh petani rata-rata sebanyak 2-6 kali. Setiap petani mempunyai intensitas kegiatan penyiangan yang berbeda-beda tetapi dari hasil wawancara minimal 2 kali dilakukan penyiangan dan maksimal 6 kali dalam sekali musim tanam. Kegiatan penyiangan ini dilakukan atau disesuaikan dengan kondisi keberadaan gulma pada bedeng tanaman. tetapi terkadang petani juga malas untuk melakukan penyingan sehingga ini kan menyebabkan rentannya tanaman sawi terserang hama atau penyakit.

\section{d. Pemupukan}

Pemupukan dilakukan dengan menggunakan beberapa macam pupuk baik dengan menggunakan pupuk organik maupun anorganik. Dari hasil wawancara dengan petani, terdapat beberapa yang menggunakan pupuk organik tetapi beberapa lainnya menggunakan pupuk anorganik berupa pupuk urea dan phonska. Pemupukan dengan menggunakan pupuk organik 
diberikan pada saat pengolahan dan penggemburan tanah. Selanjutnya akan dilakukan pemupukan dengan pupuk urea atau phonska diberikan pada saat tanaman berumur 2-3 minggu setelah tanam. Pemberian pupuk juga tidak berdasar pada aturan dosis tertentu sehingga pupuk yang diberikan akan disebar pada tanaman dengan jumlah yang tidak bisa diperkirakan.

\section{e. Pemberantasan Hama dan Penyakit}

Dari hasil wawancara dengan petani, rata-rata jenis hama yang menyerang pertanaman sawi di Distrik Aimas adalah ulat titik, belalang dan keong. Sedangkan jenis penyakit yang menyerang lahan pertanaman sawi di Distrik Aimas adalah busuk akar, bercak daun. Guna mengatasi serangan hama, petani melakukan penyemprotan dengan menggunakan pestisida dengan merek dagang prevathon yang dapat mengendalikan hama belalang, wereng, walang sangit, orong-orong, ulat grayak dan hama perisak daun. Pemberian atau penyemprotan pestisida biosanya dilakukan petani dengan rata-rata intensitas pemberian sebanyak 2 kali dalam sekali musim tanam.

\section{Panen}

\section{a. Umur Panen}

Waktu panen yang tepat adalah dengan memperhatikan bentuk fisik, warna daun dan ukuran daun. Pemanenan tanaman Sawi yang dilakukan petani di Distrik Aimas ratarata ketika umur tanaman sawi sudah mencapai umur 25-30 hari sudah dapat dipanen. Jika dibandingkan dengan sistem budidaya tanaman sawi, pemanenan biasanya dilakukan pada saat umur tanaman mencapai 70 hari atau minimal mencapai umur 40 hari.
Adanya pemanenan yang lebih cepat ini sehinngga menyebabkan periode penanaman tanaman sawi dapat dilakukan dalam 12 kali penanaman dalam setahun. Sehingga hal dapat penyebabkan penurunan produktivitas tanah dan tingkat ketergantungan akan penggunaan pupuk dan pestisida juga meningkat guna meningkatkan produktivitas tanaman.

\section{b. Cara Panen}

Pemanenan terhadap tanaman sawi yang dilakukan rata-rata petani yaitu dengan 2 cara yaitu mencabut seluruh tanaman beserta akarnya dan dengan memotong bagian pangkal batang yang berada di atas tanah dengan pisau tajam dan kemudian dibersihkan.

\section{KESIMPULAN}

Dari hasil wawancara dan pembahasan hasil penelitian maka dapat disimpulkan bahwa petani budidaya tanaman sawi di Distrik Aimas masih melakukan kegiatan budidaya tanaman sawi yang belum sesuai standar yang ada seperti pada kegiatan pemupukan yang dilakukan dengan sistem tabur, dtidak digunakan jarak tenam tertentu karena benih menggunakan sistem sebar pada areal lahan sehingga kepadatan tanaman tinggi dan ketergantungan pada pemberian pupuk anorganik.

\section{DAFTAR PUSTAKA}

Anonim, 2010.Budidaya Sawi Organik. http://UncategorizedGoBlokme.html (Diakses pada tanggal 29 april 2014)

Cahyono, Bambang, 2003. Teknik dan Strategi Budidaya Sawi Hijau (Pai-Tsai). Yayasan Pustaka Nusatama. Yogyakarta 


\section{Median Volume IX Nomor 1 Bulan Februari}

Haryanto, E.T. Suhartini dan E. Rahayu. 2001. Sawi dan Selada. PT Penebar Swadaya. Jakarta

Margiyanto E., 2010. Budidaya

Tanaman Sawi. Cahaya Tani http://Budidaya

Tanaman.Sawi.Cahaya.Tani.html .( Diakses pada tanggal 29 april 2014)

Palungkun, D. dan A. Budiarti, 2006. Sayur Komersial. PT. Penebar Swadaya, Jakarta.

Rianto, 2009. Cara Menanam Sawi. http://tips-cara-menanam- sawi.htm. ( Diakses pada tanggal 29 april 2014)

Rukmana, Rahmat, 2007. Bertanam Petsai dan Sawi. Edisi Revisi, Kanisius, Jakarta.

Tyndall, 1986. Bertanam Sawi. Swadaya Jakarta

Warsito, D.P dan Soedijanto. 1982. Saturan Daun. PT. Bumi Restu jakarta

Yudharta, 2010. Tanaman Sawi http://Tanaman.Sawi.Communi ty Aji Chrw-95\%.htm .) Diakses pada tanggal 29 april 2014 